\title{
A REFORMA OFICIAL DO ENSINO JURÍDICO NO BRASIL
}

\author{
Carlos Alberto Bittar \\ Professor Titular do Departamento de Direito Civil \\ da Faculdade de Direito da Universidade de São Paulo \\ Juiz do Primeiro Tribunal de Alçada Civil
}

\begin{abstract}
Resumo:
Reforma oficial foi processada no ensino jurídico no Brasil, de que são abordados os aspectos mais relevantes, a saber, o da necessidade de conjugação entre teoria e prática; ou da execução da parte prática com a participação dos alunos e o da exigência de apresentação de tese de láurea para conclusão do curso.
\end{abstract}

\begin{abstract}
:
Law teaching system in Brazil has gone through an official reform, whose most relevant aspects are analyzed here, namely the need for the interconnection of theory and practice, the participation of the pupils in the practical studies and the demand of the presentation of a final thesis for the course to be finished.
\end{abstract}

1. Texto normativo de grande relevo foi editado pelo Ministério da Educação e do Desporto, a saber, a Portaria n. 1.886, de 30/12/94, através da qual se realiza, oficialmente, reformulação no ensino jurídico em nosso País.

2. Com efeito, sob a epígrafe de comando destinado à fixação de diretrizes curriculares e de conteúdo mínimo para o curso jurídico, o diploma em questão contém, em verdade, importantes modificações na disciplinação jurídica do ensino do Direito, acolhendo, para nossa satisfação, idéias e sugestões que, como professor universitário, oferecemos, em longo trabalho que, preparado em 1985, foi discutido em vários congressos, conclaves e seminários e publicado na Revista da Faculdade de Direito da USP, sob o título Reforma do Currículo da Faculdade, 1986 , v. 81 , p. 117 e ss.

3. Centra-se o nóvel regulamento em três posturas básicas, todas elas defendidas em nosso referido texto, a saber: a) necessidade de conjugação de teoria e de prática na ministração do curso; b) execução da parte prática através de mecanismos vários de participação e de integração dos alunos; c) apresentação e defesa de monografia final para a conclusão do curso. 
4. Inspirada em precedentes existentes, em particular em certos países da Europa continental, a reforma ora efetivada contribuirá, em nosso entender, para o aperfeiçoamento do sistema de aprendizado do Direito, tendo, no mínimo, o mérito de haver definido posições e estabelecido diretrizes, em campo entrecortado, de há muito, por debates e por dissensões, muitas vezes ideológicas e radicais, a respeito da melhor fórmula para solução de tão decantada crise do ensino jurídico.

5. Eleitos os parâmetros expostos, tem-se ora nortes oficiais a que se deverão submeter entidades, públicas e privadas, que atuam nesse tão importante segmento da vida social, a fim de que possam estabelecer cursos coerentes com a evolução processada nessa área.

6. Não se pode mais, com efeito, cogitar de ensino puramente teórico, ou puramente prático, pois ambos acabam por acarretar distorções na formação do bacharel, que, como os demais diplomados em curso superior, tem de ser pessoa dotada de conhecimentos próprios, consciente e integrada ao mundo em que vive, como sustentamos no referido estudo.

7. Ademais, a submissão do aluno, em cursos teóricos, a certos e específicos estágios, sem uma participação, em classe e/ou em campo, de atividades práticas e, mesmo de debates jurídicos, não lhe confere a necessária destreza para o futuro exercício da atividade de sua habilitação. Entendemos sempre, ao revés, que nos bancos escolares deve o aluno também se preparar para os embates da vida profissional: daí, a utilização de mecanismos diversos de atuação prática do aluno, seja em seminários, seja na preparação e na discussão de casos, seja em debates, em aula, sobre temas de interesse sócio-jurídico, seja na consecução de trabalhos escritos e assim por diante.

8. Por essa razão é que propusemos, então, a modificação do sentido do curso de bacharelado, em nossa Faculdade, no chamado ciclo de especialização ( $5^{\circ}$ ano), sugerindo, ademais, a instituição da chamada "tese de láurea" ora prevista na Portaria referida como requisito necessário para a conclusão do curso.

9. Precedidos de orientação, direcionados para o debate de questões de interesse social no momento, cercados de estudos, pesquisas e meditações, podem os trabalhos resultantes, a par do preenchimento da finalidade precípua, vir a constituirse em valiosas contribuições de jovens bacharelandos para o próprio aperfeiçoamento das instituições do País.

10. Experiência nesse sentido efetivamos, com a interessada e produtiva turma de bacharelandos de 1988 , do curso diurno de nossa tradicional 
Faculdade, com efeitos extremamente satisfatórios, haja visto o nível dos trabalhos então oferecidos, muitos dos quais foram depois publicados, em livros, em coletâneas e em periódicos especializados.

11. De outro lado, o novo sistema propicia aos examinadores a possibilidade de aferir, com elementos mais expressivos do que as simples provas e trabalhos curriculares, a capacidade de organização de raciocínio e de decisão do candidato, fatores esses que entendemos fundamentais para a posterior atuação em qualquer das diferentes habilitações que ao diploma de bacharel em Direito se descortinam no mundo profissional.

12. Ora, como se encontra em vigor desde a data de sua publicação (D.O.U. de 4/1/95, p. 238) tendo, ademais, revogado disposições em contrário, consubstancia a referida Portaria a nova ordem oficial para o ensino do Direito, a que se deverão adaptar, em consonância com os seus termos, as Faculdades existentes, nos prazos e nas condições constantes de seu texto.

13. Acentue-se, por fim à guisa de colaboração para a respectiva análise, que, a par das linhas básicas assinaladas, são as seguintes as orientações principais do novo regime:

a. Necessidade de aparelhamento da Faculdade com acervo bibliográfico mínimo;

b. Obrigatoriedade de observância do número mínimo de horas para o curso;

c. Necessidade de inserção de atividades de pesquisa e de outras medidas complementares, de cunho prático, no desenvolvimento do curso;

d. Manutenção de currículo mínimo, distribuídas as matérias em fundamentais e profissionalizantes;

e. Adoção da diretriz de interdisciplinariedade na introdução de novas disciplinas;

f. Manutenção do sistema de especialização, realizável agora a partir do $4^{\circ}$ ano;

g. Obrigatoriedade do estágio de prática jurídica, supervisionado pela entidade de ensino, como integrante do currículo pleno;

h. Possibilidade de realização, em convênio com a $\mathrm{OAB}$, do estágio profissional de advocacia.

14. Com essas orientações e uma vez feitos os necessários ajustes pelas entidades destinatárias, abrir-se-ão novas perspectivas aos cursos jurídicos, 
com reflexos positivos em todas as áreas em que a ação do bacharel se possa fazer sentir.

15. Cumpre, pois, que se entenda o real significado da reforma e que para ela convirjam as orientações de entidades, de docentes e, enfim, de todos que participam da nobre atividade de ministração de ensino, a fim de que se realizem, efetivamente, os altos objetivos colimados pelo legislador e por aqueles que, como nós, se têm empenhado nessa ingente tarefa de busca do aprimoramento do ensino do Direito. 